\title{
Performans Ayam Ketarras pada Umur 2 Sampai 12 Minggu Berdasarkan Pola Warna Bulu
}

\author{
Performance of Ketarras Chicken at 2 to 12 Weeks Based on Feather Color Pattern \\ M. A. Hidayatullah, Kususiyah, dan D. Kaharuddin \\ Jurusan Peternakan, Fakultas Pertanian, Universitas Bengkulu \\ Jalan Raya, W. R Supratman, Kandang Limun, Bengkulu, 38371A \\ Corresponding e-mail: muhammadazizhidayatullah.ptr14@gmail.com
}

\begin{abstract}
This study aimed to evaluate the performance of Ketarras chicken at the age of 2-12 weeks based on feather color patterns. This research was conducted in June to August 2017 at the cage of the Commercial Zone Animal Laboratory (CZAL) Department of Animal Husbandry, Faculty of Agriculture, University of Bengkulu. This study used a completely randomized design with 3 treatments of 20 replications. The treatments tried were the color pattern of feathers with $\mathrm{P} 1=$ Dark fur color pattern (dark brown), $\mathrm{P} 2=$ Blurik white fur pattern and P3 = White fur color pattern. Each replication used 2 chickens, so that each color of the chicken feather pattern is needed 20 chickens that are placed randomly on the individual bat cage. The variables observed were ration consumption, growth, and ration conversion. The results of the variance analysis showed that feed consumption, body weight, weight gain and ration conversion of each treatment from the ages of 2 to 12 weeks were not significantly different $(\mathrm{P}>0.05)$ with cumulative ration consumption average age 2-12 weeks P1 (2930, $20 \mathrm{~g} /$ head), P2 (2919.53 g / head) and P3 (2872.08 g / head). Achievement of 12 weeks body weights were at treatment P1 (745.80 g / head), P2 (797.53 g / head) and P3 (758.60 g / head). Cumulative weight gains were P1 (640.88 g / head), P2 (697.38 g / head), and P3 (660.90 g / head). Conversion of treatment rations were P1 (4.60), P2 (4.24) and P3 (4.40). It can be concluded that the difference in color patterns of Ketarras chicken feathers did not cause different performance at the age of 2 to 12 weeks.
\end{abstract}

Key words: Performance, growth, chicken Ketarras

\begin{abstract}
ABSTRAK
Penelitian ini bertujuan untuk mengevaluasi performans ayam Ketarras pada umur 2-12 minggu berdasarkan pola warna bulu. Penelitian ini dilaksanakan pada bulan Juni sampai bulan Agustus 2017 di kandang Commercial Zone Animal Laboratory (CZAL) Jurusan Peternakan Fakultas Pertanian Universitas Bengkulu. Penelitian ini menggunakan rancangan acak lengkap dengan 3 perlakuan 20 ulangan. Perlakuan yang dicobakan adalah pola warna bulu dengan P1 = Pola warna bulu gelap (coklat hitam), P2 = Pola warna bulu putih blurik dan P3 = Pola warna bulu putih. Setiap ulangan menggunakan 2 ekor ayam, sehingga masing masing pola warna bulu ayam yang dibutuhkan 20 ekor ayam yang ditempatkan secara acak pada kandang batteray individu. Variabel yang diamati adalah konsumsi ransum, pertumbuhan, dan konversi ransum. Hasil analisis ragam menunjukkan bahwa konsumsi ransum, berat badan, pertambahan berat badan dan konversi ransum masing masing perlakuan mulai umur 2 sampai 12 minggu berbeda tidak nyata $(P>0,05)$ dengan rataan konsumsi ransum kumulatif umur 2-12 minggu P1 (2930,20 g/ekor), P2 (2919,53 g/ekor) dan P3 (2872,08 g/ekor). Capaian berat badan umur 12 minggu pada perlakuan P1 (745,80 g/ekor), P2 (797,53 g/ekor) dan P3 (758,60 g/ekor). Pertambahan berat badan kumulatif P1 (640,88 g/ekor), P2 (697,38 g/ekor), dan P3 (660,90 g/ekor). Konversi ransum perlakuan P1 $(4,60)$, P2 $(4,24)$ dan P3 $(4,40)$. Dapat disimpulkan bahwa perbedaan pola warna bulu ayam Ketarras tidak menyebabkan performans berbeda pada umur 2 sampai 12 minggu.
\end{abstract}

Kata kunci : Performans, pertumbuhan, ayam Ketarras

\section{PENDAHULUAN}

Permintaan konsumen akan telur ayam kampung yang terus meningkat disikapi oleh peternak dengan memelihara ayam Arab untuk memenuhi kebutuhan telur ayam kampung. Ayam Arab (Gallus turcicus) merupakan salah satu ayam buras yang sudah beradaptasi di Indonesia. Ayam ini bersifat gesit, aktif dan memiliki daya tahan tubuh yang kuat (Darmana dan Sitanggang, 2002). 
Penampilan ayam Arab lebih menarik dibandingkan dengan ayam Buras lainnya. Ayam ini mempunyai warna bulu dari kepala hingga leher putih keperakan dan warna bulu totol hitam putih/lurik hitam putih dan lebih homogen dengan warna dasar hitam dihiasi warna putih di daerah kepala, leher, dada, punggung dan sayap (Natalia et al., 2005)

Ayam Arab ada dua jenis, yaitu ayam Arab Silver (braekel kriel silver) dan ayam Arab Golden (braekel kriel gold). Ayam Arab Silver lebih banyak dikenal dan dibudidayakan dibandingkan ayam Arab Golden. Kedua jenis ayam Arab ini dibedakan pada warna bulunya. Ayam Arab Silver mempunyai warna bulu dari kepala hingga leher putih keperakan dan warna bulu badan totol hitam putih (lurik) hitam putih. Adapun ayam Arab Golden memiliki ciri khas warna bulu kepala sampai leher keemasan dan warna bulu badan totol keemasan (Natalia et al., 2005).

Menurut Nataamijaya (2003) ayam Arab memiliki sifat kualitatif antara lain berjengger tunggal (single) dan berwarna merah, pial berwarna merah, memiliki warna bulu seragam dengan warna dasar hitam dihiasi dengan warna putih di bagian kepala, leher, dada, punggung dan sayap serta berwarna putih pada paruh, kulit dan sisik kaki.

Salah satu cara mendapatkan bibit yang unggul adalah dengan melakukan persilangan. Telah dilakukan persilangan antara ayam Arab jantan dengan ayam Ras Petelur Coklat betina. Hasil dari persilangann tersebut dinamakan ayam Arras dengan komposisi genetik $50 \%$ ayam Ras dan $50 \%$ ayam Arab. Hasil persilangan ini menunjukkan adanya sifat kualitatif dan kuantitatif. Sifat kualitatif pada ayam Arras ditandai adanya pola warna bulu yang beragam, sedangkan sifat kuantitaif ditandai dengan produksi telur sudah cukup baik, namun warna kerabang telur ayam Arras yang dihasilkan lebih dominan menyerupai warna kerabang telur ayam Ras, sehingga masih mempunyai nilai harga jual yang lebih rendah dibanding dengan harga telur ayam Kampung (Galih, 2017). Lebih lanjut dinyatakan bahwa ukuran telur ayam Arras masih cenderung lebih besar dibanding dengan telur ayam kampong. Memperhatikan hal tersebut diatas maka ayam Arras betina disilangkan dengan ayam Arab jantan, sehingga diperoleh keturunan dengan komposisi genetik 25\% ayam Ras dan $75 \%$ ayam Arab.

Hasil persilangan ini dinamakan ayam Ketarras. Persilangan tersebut diharapkan ada efek complementer yaitu bisa menghasilkan telur putih kecokelatan sebagaimana warna telur ayam kampung dengan produktifitas yang tinggi. Warna kerabang telur ayam Ketarras sudah cukup bagus dibanding warna kerabang telur ayam Arras. Secara umum masyarakat telah bisa menerima telur ayam Ketarras sebagai telur ayam kampung (Marliya, 2017). Hal ini disebabkan warna kerabang telur ayam Ketarras sudah mirip dengan warna kerabang telur ayam Kampung. Berkaitan dengan hal tersebut, ayam Ketarras perlu digali lebih lanjut potensi produksinya. Dari persilangan tersebut, terlihat adanya warna bulu yang sangat beragam seperti bulu warna coklat, hitam dan putih. Hal ini menunjukkan sifat kualitatif yang beda dengan tetuanya. Diharapkan dari hasil persilangan tersebut dapat menaikkan performan hasil silangannya melampaui rata-rata performa kedua tetuanya.

Fase kritis pemeliharaan ayam petelur adalah pada awal pemeliharaan (priode starter). Keberhasilan menciptakan kondisi yang optimal bagi tumbuh kembang anak ayam hingga pullet menjadi modal dasar suksesnya peternakan ayam petelur. Periode ini merupakan kesempatan untuk mengejar target berat badan sehingga ransum yang diberikan harus mempunyai nilai nutrisi yang baik untuk pertumbuhan otot (Rasyaf, 2012 ${ }^{\mathrm{b}}$ ). Menurut Pambudhi (2003) disitasi oleh Diana (2012) periode starter pada ayam arab terdiri dari dua fase yaitu fase starter I umur 1-6 minggu dan fase starter II umur 712 minggu. Fase starter ini sangat penting, karena fase ini dapat mempengaruhi saat produksi

nanti. 
Penelitian ini, dilakukan persilangan antara Ayam Ketarras jantan dengan Ayam Ketarras betina untuk melihat sifat genetik dari tetuanya, terutama pada pola warna bulu yang sangat beragam. Variasi warna bulu pada ayam disebabkan oleh faktor genetik. Pemunculan warna bulu ditentukan secara genetik baik oleh gen dominan maupun resesif (Jull, 1951) disitasi oleh Johari et al. (2009)

Berdasarkan uraian tersebut di atas, penulis melakukan penelitian tentang performans ayam Ketarras pada umur 2 sampai 12 minggu berdasarkan pola warna bulu. Penelitian ini bertujuan untuk mengevaluasi performans ayam Ketarras sejak umur 2 sampai 12 minggu berdasarkan pola warna bulu. Performans ayam Ketarras pada umur 2 sampai 12 minggu dengan pola warna bulu berbeda diduga berbeda.

\section{METODE PENELITIAN}

Penelitian ini berjudul "Performans Ayam Ketarras pada umur 2 sampai 12 minggu berdasarkan pola warna bulu" yang dilaksanakan selama \pm 3 bulan dimulai sejak bulan Juni sampai bulan Agustus 2017 di kandang Comercial Zone Animal Laboratory (CZAL) Jurusan Peternakan Fakultas Pertanian Universitas Bengkulu.

Peralatan yang digunakan pada penelitian ini adalah mesin tetas, kandang batteray individu, kandang brooder, ayam ketarras jantan dan betina, timbangan, ember, sapu, desinfektan, tempat pakan, dan tempat minum ternak.

Bahan yang digunakan dalam penelitian ini yaitu ayam Ketarras umur 2 minggu, serta bahan pakan yang terdiri dari dedak, jagung giling dan KLK (Konsentrat Layer Khusus).

Tahapan penelitian terbagi menjadi 3 bagian yaitu mengawinkan ayam Ketarras pejantan dan ayam Ketarras betina, persiapan kandang dan pemeliharaan.

Ayam pejantaan Ketaras dan ayam betina Ketarras dipelihara pada kandang postal ukuran $2 \mathrm{~m} \mathrm{X} 5 \mathrm{~m}$ dengan rasio 1:6. Jumlah kandang pemeliharaan ada dua petak sehingga terdapat 2 ekor pejantan dan 12 ekor betina. Koleksi akan dimulai setelah induk dipelihara selama 2 minggu.

Kandang yang digunakan pada penelitian ini adalah kandang batteray individu sebanyak 60 petak, setiap unitnya berukuran panjang $50 \mathrm{~cm}$, tinggi $50 \mathrm{~cm}$ dan lebar $23 \mathrm{~cm}$. Kandang batteray dilengkapi dengan tempat minum dan tempat pakan.

Persiapan kandang sebelum dilaksanakan penelitian adalah sanitasi kandang, pembersihan kandang dari semua kotoran, membersihkan tempat pakan dan minum.

Pemeliharaan ayam dilakukan 2 tahap. Tahap pertama, ayam dipelihara bersama saat umur 0 - 2 minggu dan tahap kedua, ayam dipelihara di kandang batteray mulai umur 2 minggu sampai umur 12 minggu.

Kandang brooding telah dipersiapkan sebelum DOC menetas. DOC dipelihara kedalam kandang brooder lampu 40 watt yang dinyalakan selama 24 jam sampai ayam berumur 14 hari atau disesuaikan dengan kondisi suhu lingkungan. Setelah 2 minggu, ayam dipindahkan kedalam kandang batteray. Pemberian ransum dilakukan 2 kali sehari yaitu pada pukul 07.00 WIB dan 16.00 WIB. Ransum diberikan ad libitum. Ransum yang digunakan adalah ransum komersial BR 1 selama 2 minggu.

\section{Pemeliharaan Ayam Umur 2-12 Minggu}

Setelah anak ayam berumur 2 minggu, anak ayam dipelihara pada kandang perlakuan sampai berumur 12 minggu. Selama perlakuan, anak ayam diberi ransum dengan kandungan protein $18 \%$ dan energi $2.800 \mathrm{kkal} / \mathrm{kg}$ (NRC, 1994). Tempat air minum dibersihkan setiap akan dilakukan pergantian air minum. Penimbangan berat badan dilakukan setiap 1 minggu sekali untuk mengetahui pertumbuhannya sampai umur 12 minggu. Kandungan nutrisi bahan penyusun ransum disajikan pada Tabel 1. 
Tabel 8. Kandungan nutrisi bahan penyusun ransum

\begin{tabular}{lcccccc}
\hline $\begin{array}{c}\text { Bahan Penyusun } \\
\text { Ransum }\end{array}$ & $\begin{array}{c}\text { PK } \\
(\%)\end{array}$ & $\begin{array}{c}\text { ME } \\
(\mathrm{kkal} / \mathrm{kg})\end{array}$ & $\begin{array}{c}\text { SK } \\
(\%)\end{array}$ & $\begin{array}{c}\text { Lemak } \\
(\%)\end{array}$ & $\begin{array}{c}\text { Ca } \\
(\%)\end{array}$ & $\begin{array}{c}\text { P } \\
(\%)\end{array}$ \\
\hline Dedak $^{\mathrm{a}}$ & 11,9 & 2460 & 12 & 9,78 & 0,01 & 1,3 \\
Jagung $^{\text {a }}$ & 8,9 & 3321 & 2,5 & 2,97 & 0,02 & 0,23 \\
$\mathrm{KLK}^{\mathrm{b}}$ & 33 & 2700 & 9,83 & 6,37 & 10,87 & 1,28 \\
$\mathrm{BR}^{\mathrm{c}}$ & 21 & 2900 & 4,5 & 4 & 1 & 0,8 \\
\hline
\end{tabular}

a. Hartadi et al. (2005), b. Label KLK (PT. Japfa Comfeed), c. Label BR1

Komposisi dan kandungan nutrisi ransum ayam petelur umur 0-12 minggu dan umur 2-12 minggu disajikan pada Tabel 2.

Tabel 2. Susunan ransum dan kandungan zat gizi ayam petelur umur $0-2$ minggu dan umur 2-12 minggu.

\begin{tabular}{lll}
\hline $\begin{array}{l}\text { Kandungan } \\
\text { Pakan }\end{array}$ & $\begin{array}{l}0-2 \\
\text { minggu }\end{array}$ & $\begin{array}{l}2-12 \\
\text { minggu }\end{array}$ \\
\hline BR 1 & $75,5 \%$ & - \\
KLK & - & $35 \%$ \\
Dedak & - & $35 \%$ \\
Jagung giling & $24,5 \%$ & $30 \%$ \\
\hline Jumlah & $100 \%$ & $100 \%$ \\
\hline Protein Kasar & $18,3 \%$ & $18,38 \%$ \\
Energi (kka1/kg) & 3003,1 & 2802,3 \\
Serat Kasar & $4,01 \%$ & $7,40 \%$ \\
Lemak Kasar & $3,74 \%$ & $6,54 \%$ \\
Kalsium & $0,75 \%$ & $3,85 \%$ \\
Fosfor & $0,48 \%$ & $0,97 \%$ \\
\hline
\end{tabular}

Pemberian pakan berdasarkan umur mengacu pada Amrullah (2003) pada Tabel 3 berikut.

Tabel 3. Konsumsi ransum ayam petelur

\begin{tabular}{cc}
\hline Umur (minggu) & $\begin{array}{c}\text { Ayam Petelur } \\
\text { (g/ekor/minggu })\end{array}$ \\
\hline 0 & 50 \\
2 & 140 \\
4 & 260 \\
6 & 340 \\
8 & 360 \\
10 & 380 \\
12 & 400 \\
\hline
\end{tabular}

Sumber (Amrullah, 2003)

\section{Rancangan Penelitian dan Variabel yang diamati}

Penelitian ini menggunakan Rancangan ulangan. Faktor perbedaan pola warna bulu yang digunakan sebagai perlakuan, yaitu :

P1 = Pola warna bulu gelap (coklat hitam)

P2 = Pola warna bulu putih blurik

P3 = Pola warna bulu putih

Setiap ulangan menggunakan 2 ekor ayam, sehingga masing - masing jenis ayam dibutuhkan 40 ekor. Ayam ditempatkan secara acak pada kandang batteray.

Variabel yang diamati meliputi konsumsi ransum, berat badan, pertambahan berat badan dan konversi ransum.

\section{Konsumsi Ransum}

Konsumsi ransum dapat diketahui dengan menghitung jumlah ransum yang diberikan pada awal minggu dikurangi dengan sisa ransum pada akhir minggu.

Konsumsi Ransum (g/ekor/minggu)

$=\frac{\text { Ransum yang disediakan }(\mathrm{g})-\text { Ransum sisa }(\mathrm{g})}{\text { jumlah ayam (ekor) }}$

Konsumsi Ransum Kumulatif (g/ekor)

$=\frac{\text { Konsumsi ransum minggu } 3(\mathrm{~g})+\ldots \text { minggu } 12(\mathrm{~g})}{\text { jumlah ayam (ekor) }}$

\section{Berat Badan Mingguan}

Berat badan diukur dengan menimbang ayam seminggu sekali dimulai pada saat umur 2 minggu sampai 12 minggu.

\section{Pertambahan berat badan mingguan}

Pertambahan berat badan diukur setiap minggu dengan cara berat badan akhir minggu (berat akhir) dikurang berat badan minggu sebelumnya (berat awal).

$$
\operatorname{PBB}(\mathrm{g})=\mathrm{BB}_{\mathrm{t}}(\mathrm{g})-\mathrm{BB}_{\mathrm{t}-1}(\mathrm{~g})
$$

Acak Lengkap 3 perlakuan dengan 20 
Keterangan :

PBB = Pertambahan berat badan

$\mathrm{BB}_{\mathrm{t}} \quad=$ Berat badan akhir minggu

$\mathrm{BB}_{\mathrm{t}-1}=$ Berat badan minggu sebelumnya

$\mathrm{t}=$ Waktu pengukuran (satu minggu)

PBB kumulatif $=$ berat badan akhir penelitian - berat badan awal penelitian

\section{Konversi Ransum}

Konversi Ransum merupakan perbandingan antara jumlah ransum yang dikonsumsi dengan pertambahan berat badan.

Konversi Ransum Mingguan

$=\frac{\text { Total konsumsi ransum selama } 1 \text { minggu }}{\text { Pertambahan berat badan selama } 1 \text { minggu }}$

Konversi Ransum Kumulatif

$$
=\frac{\text { Konsumsi kumulatif }}{\text { PBB kumulatif }}
$$

\section{Analisis Data}

Data yang diperoleh dianalisis menggunakan ANOVA dan jika terdapat pengaruh yang nyata $(\mathrm{P}<0,05)$ maka diuji lanjut dengan Duncan's Multiple Range Test (DMRT) untuk melihat perbedaan antar perlakuan (Yitnosumarto, 1993).

\section{HASIL DAN PEMBAHASAN}

\section{Konsumsi ransum}

Rataan konsumsi ransum ayam Ketarras umur 2 sampai 12 minggu berdasarkan pola warna bulu dapat dilihat pada Tabel 4. Hasil analisis ragam menunjukkan bahwa perbedaan pola warna bulu berpengaruh tidak nyata $(\mathrm{P}>0,05)$ kecuali pada minggu ke 2-4, 2-6, 2-7, 2-11, 2-12 $(\mathrm{P}<0,05)$. Terlihat dari tabel tersebut bahwa konsumsi ransum kumulatif pada pola warna bulu putih (P3) umur 2-4, 2-6, 2-7, 211 dan 2-12 lebih rendah. Konsumsi ransum ayam ketarras umur 2 sampai 12 minggu pada perlakuan P1 (2930,20 g), P2 (2919,53 g) dan P3 $(2872,08$ g). Terdapatnya perbedaan jumlah konsumsi ransum pada masing masing pola warna bulu ini disebabkan karena jenis kelamin jantan pada pola warna bulu gelap (P1) dan pola warna bulu putih blurik (P2) lebih banyak dibandingkan dengan pola warna putih (P3). Menurut Astuti (2012) konsumsi ransum dipengaruhi oleh faktor ukuran tubuh, kualitas ransum yang diberikan, jenis kelamin dan juga jenis ayam. Kualitas ransum yang digunakan pada pemeliharaan ini sama.

Tabel 4. Rataan konsumsi ransum kumulatif ayam Ketarras pada umur 2 sampai 12 minggu berdasarkan pola warna bulu

\begin{tabular}{|c|c|c|c|c|}
\hline \multirow{2}{*}{$\begin{array}{c}\text { Umur } \\
(\mathrm{minggu})\end{array}$} & \multicolumn{3}{|c|}{ Perlakuan } & \multirow{2}{*}{ Ket } \\
\hline & P1 & P2 & P3 & \\
\hline \multicolumn{5}{|c|}{ 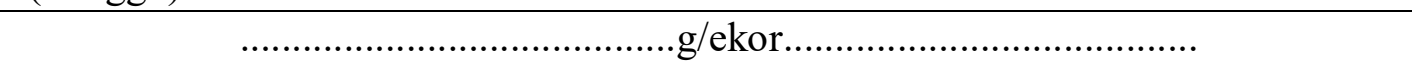 } \\
\hline $2-3$ & 99,20 & 106,00 & 101,45 & ns \\
\hline $2-4$ & $243,68^{\mathrm{a}}$ & $253,40^{\mathrm{b}}$ & $249,20^{\mathrm{a}}$ & $*$ \\
\hline $2-5$ & 445,28 & 458,08 & 447,73 & ns \\
\hline $2-6$ & $704,18^{\mathrm{a}}$ & $723,80^{\mathrm{a}}$ & $689,13^{\mathrm{b}}$ & $*$ \\
\hline $2-7$ & $1018,23^{\mathrm{a}}$ & $1025,53^{\mathrm{a}}$ & $990,05^{\mathrm{b}}$ & * \\
\hline $2-8$ & 1379,00 & 1379,90 & 1348,18 & ns \\
\hline $2-9$ & 1745,78 & 1741,63 & 1709,90 & ns \\
\hline $2-10$ & 2128,23 & 2121,80 & 2084,63 & ns \\
\hline $2-11$ & $2525,80^{\mathrm{a}}$ & $2514,33^{\mathrm{a}}$ & $2470,98^{b}$ & $*$ \\
\hline $2-12$ & $2930,20^{\mathrm{a}}$ & $2919,53^{\mathrm{a}}$ & $2872,08^{b}$ & $*$ \\
\hline
\end{tabular}

Keterangan: $\mathrm{P} 1=$ Pola warna bulu gelap (coklat hitam)

P2 = Pola warna bulu putih blurik

P3 = Pola warna bulu putih

ns $=$ berbeda tidak nyata $(\mathrm{P}>0,05)$ 
Sifat kualitatif sedikit hubungannya dengan produksi tetapi dapat dijadikan sebagai dasar dalam pengembangan ternak pada masa yang akan datang, hal ini sesuai dengan pernyataan Warwick dan Legates (1986) walaupun sedikit hubungannya dengan produksi, sifat kualitatif mungkin penting sebagai pertimbangan dalam program pemuliaan pada masa yang akan datang.Tidak terdapatnya perbedaan yang nyata dari konsumsi ransum pada masing masing pola warna bulu dapat dilihat pada Gambar 1.

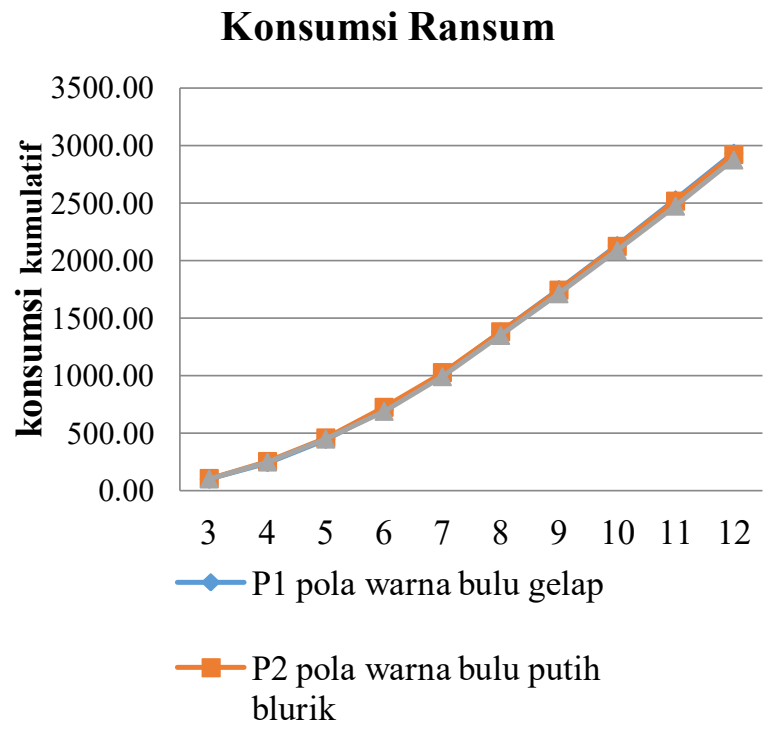

Gambar 1. Grafik Konsumsi ransum kumulatif ayam Ketarras pada umur 2 sampai 12 minggu

Grafik menunjukkan bahwa konsumsi ransum kumulatif dari masing masing pola warna bulu meningkat dengan bertambahnya umur ayam. Menurut Sukarini dan Rifai (2011) konsumsi ransum dibutuhkan untuk memenuhi kebutuhan energi hidup pokok dan selebihnya akan digunakan untuk pertumbuhan dan proses produksi telur.

Rataan konsumsi ransum ayam Ketarras pada penelitian ini berkisar 2872,08 - 2930,53 g. Gunawan (2017) melaporkan bahwa konsumsi ransum ayam Ketarras pada umur 2-12 minggu adalah $(3453,30)$ g. Bila dibandingkan dengan hasil penelitian Gunawan (2017), konsumsi ransum ayam ketarras pada penelitian ini 522,77 g lebih rendah. Terdapatnya perbedaan konsumsi ransum ayam ketarras pada penelitian ini dengan penelitian Gunawan (2017) diduga disebabkan oleh perbedaan waktu penelitian, sehingga lingkungannya berbeda.

\section{Pertumbuhan}

Pengukuran pertumbuhan ayam Ketarras pada pemeliharaan ini meliputi berat badan, pertambahan berat badan mingguan dan pertambahan berat badan kumulatif.

\section{Berat badan}

Penimbangan ayam dilakukan setiap minggu mulai umur 2 sampai 12 minggu. Rataan berat badan ayam per minggu pada masing masing pola warna bulu dapat dilihat pada Tabel 5.

Hasil analisis ragam menunjukkan bahwa perbedaan pola warna bulu berpengaruh tidak nyata $(\mathrm{P}>0,05)$ terhadap berat badan mingguan. Capaian berat badan ayam Ketarras umur 12 minggu pada perlakuan P1 (745,80 g), P2 (797,53 g) dan P3 $(758,60 \mathrm{~g})$ berbeda tidak nyata. Rataan berat badan mingguan pada penelitian ini adalah 745,80 - 797,53 g. Gunawan (2017) melaporkan bahwa berat badan mingguan ayam ketarras umur 2-12 minggu adalah 753,23 g. Bila dibandingkan dengan hasil penelitian Gunawan (2017) berat badan mingguan ayam ketarras pada penelitian ini relatif sama. Hal ini menunjukkan sifat kualitatif warna bulu tidak mempengaruhi capaian berat badan. Menurut Sukarini dan Rifai (2011), pertambahan berat badan merupakan peformans fase starter ayam petelur yang perlu diamati selain konsumsi ransum dan konversi ransum. Pencapaian berat badan yang sesuai pada fase pertumbuhan merupakan salah satu indikator utama dalam pencapaian produksi telur yang optimal pada saat berada pada fase produksi.

Berat badan ayam Ketarras berdasarkan pola warna bulu pada umur 2 sampai umur 12 minggu berbeda tidak nyata dikarenakan genetik ayam Ketarras sama. Ayam Ketarras merupakan ayam hasil persilangan dari ayam Arras (ayam Arab X ayam Ras) dengan ayam Arab (Gunawan, 2017). 
Tabel 5. Rataan berat badan mingguan ayam Ketarras pada umur 2 sampai 12 minggu berdasarkan pola warna bulu

\begin{tabular}{|c|c|c|c|c|}
\hline \multirow{2}{*}{$\begin{array}{c}\text { Umur } \\
\text { (minggu) }\end{array}$} & \multicolumn{3}{|c|}{ Perlakuan } & \multirow{2}{*}{ Ket } \\
\hline & $\mathrm{P} 1$ & P2 & P3 & \\
\hline & & ekor..... & ...… & \\
\hline 2 & 104,93 & 100,15 & 97,70 & ns \\
\hline 3 & 145,28 & 43,78 & 145,78 & ns \\
\hline 4 & 178,23 & 182,83 & 184,53 & ns \\
\hline 5 & 252,03 & 242,85 & 243,25 & ns \\
\hline 6 & 324,23 & 305,73 & 317,75 & ns \\
\hline 7 & 410,35 & 408,90 & 393,13 & ns \\
\hline 8 & 481,10 & 472,53 & 459,20 & $\mathrm{~ns}$ \\
\hline 9 & 540,48 & 542,78 & 531,98 & ns \\
\hline 10 & 614,20 & 641,58 & 607,10 & ns \\
\hline 11 & 680,60 & 723,58 & 690,28 & ns \\
\hline 12 & 745,80 & 797,53 & 758,60 & ns \\
\hline
\end{tabular}

Keterangan :

P1 = Pola warna bulu gelap (coklat hitam)

$\mathrm{P} 2$ = Pola warna bulu putih blurik

P3 = Pola warna bulu putih

ns $=$ berbeda tidak nyata $(\mathrm{P}>0,05)$

Gambar 2 menunjukan pertumbuhan ayam Ketarras berdasarkan pola warna bulu.

Berat Badan

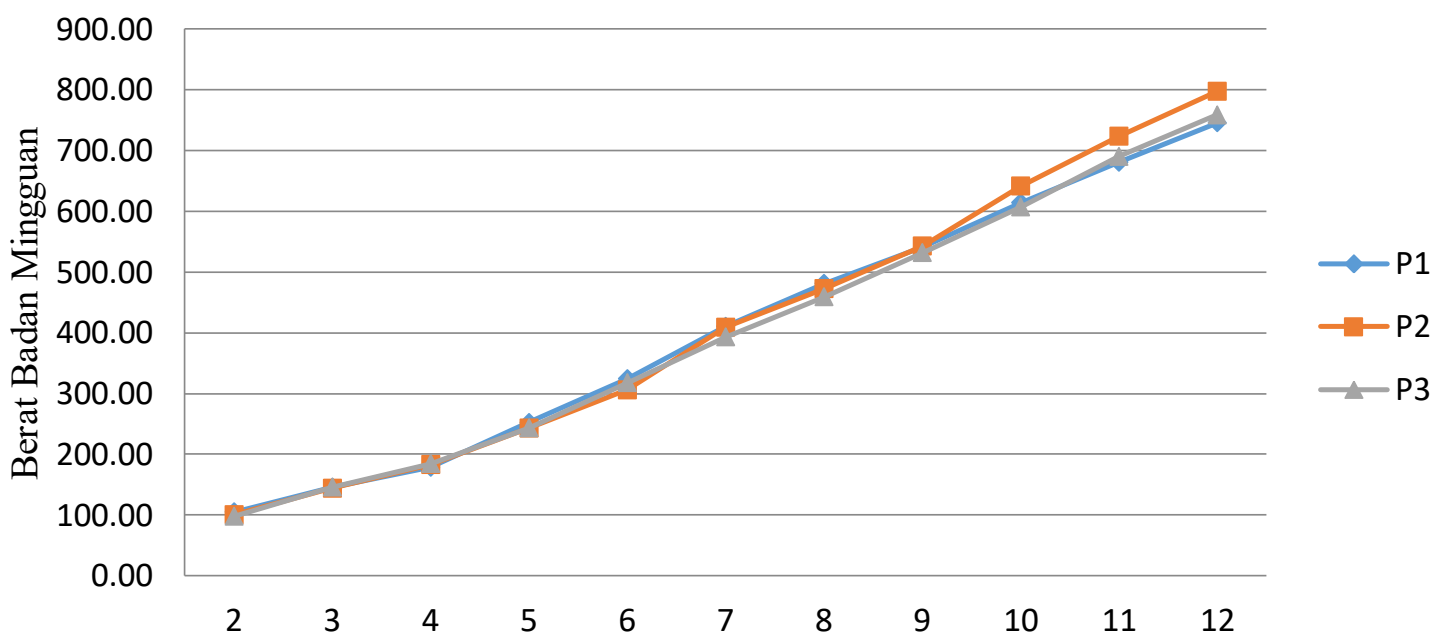

Gambar 2. Grafik berat badan ayam Kettaras pada umur 2 sampai 12 minggu

Grafik menunjukkan bahwa capaian berat badan ayam Ketarras umur 2 sampai 12 minggu relatif sama. Hal ini menunjukkan bahwa sifat kualitatif tidak mempengaruhi pertambahan berat badan ayam Ketarras. Berat badan masing-masing pola warna bulu meningkat dengan bertambahnya umur, seiring dengan meningkatnya konsumsi ransum selama umur 2-12 minggu. Rasyaf
(2011) mengemukakan bahwa ayam terus mengalami peningkatan berat badan pada masa pertumbuhan yaitu pada masa awal (masa starter).

Pertambahan berat badan

Rataan pertambahan berat badan kumulatif ayam Ketarras pada umur 2 sampai 12 minggu berdasarkan pola warna bulu dapat dilihat pada Tabel 6: 
Tabel 6. Rataan pertambahan berat badan kumulatif ayam Ketarras pada umur 2 sampai 12 minggu berdasarkan pola warna bulu

\begin{tabular}{|c|c|c|c|c|}
\hline \multirow{2}{*}{$\begin{array}{c}\text { Umur } \\
\text { (minggu) }\end{array}$} & \multicolumn{3}{|c|}{ Perlakuan } & \multirow{2}{*}{ Ket } \\
\hline & $\mathrm{P} 1$ & P2 & $\mathrm{P} 3$ & \\
\hline & & ekor... & & \\
\hline $2-3$ & 40,35 & 43,63 & 48,08 & ns \\
\hline $2-4$ & 73,30 & 82,68 & 86,83 & ns \\
\hline $2-5$ & 147,10 & 142,70 & 145,55 & ns \\
\hline $2-6$ & 219,30 & 205,58 & 220,05 & ns \\
\hline $2-7$ & 305,43 & 308,75 & 300,30 & ns \\
\hline $2-8$ & 376,18 & 372,38 & 361,50 & ns \\
\hline $2-9$ & 435,55 & 442,63 & 434,28 & ns \\
\hline $2-10$ & 509,28 & 541,43 & 509,40 & ns \\
\hline $2-11$ & 575,68 & 623,43 & 592,58 & ns \\
\hline $2-12$ & 640,88 & 697,38 & 660,90 & ns \\
\hline
\end{tabular}

Keterangan:

$$
\begin{aligned}
& \text { P1 }=\text { Pola warna bulu gelap (coklat hitam) } \\
& \text { P2 }=\text { Pola warna bulu putih blurik } \\
& \text { P3 }=\text { Pola warna bulu putih } \\
& \text { ns }=\text { berbeda tidak nyata }(\mathrm{P}>0,05)
\end{aligned}
$$

Hasil analisis ragam menunjukkan bahwa perbedaan pola warna bulu berpengaruh tidak nyata $(\mathrm{P}>0,05)$ terhadap pertambahan berat badan kumulatif. Pertambahan berat badan kumulatif ayam ketarras umur 2 - 12 minggu pada perlakuan P1 (640,88 g), P2 (697,38 g), dan P3 (660,90 g) berbeda tidak nyata. Rataan pertambahan berat badan kumulatif pada penelitian ini adalah 640,88 - 697,38 g. Gunawan (2017) melaporkan bahwa pertambahan berat badan kumulatif ayam ketarras umur 2-12 minggu adalah 645,07 g. Bila dibandingkan dengan hasil penelitian Gunawan (2017) pertambahan berat badan mingguan ayam ketarras pada penelitian ini relatif sama. Hal ini menunjukkan bahwa sifat kualitatif (warna bulu) pada ayam Ketarras tidak mempengaruhi pertambahan berat badan kumulatif. Santoso (2014) menyatakan faktor-faktor yang mempengaruhi pertambahan berat badan unggas adalah species, jenis ayam, bentuk pakan, sistem pemberian pakan, bangsa, ukuran tubuh dan berat awal. Lukman (2005) menyatakan

bahwa pertambahan berat badan sangat erat kaitannya dengan peningkatan konsumsi ransum. Konsumsi ransum akan meningkat berdasarkan pertambahan berat badan, artinya semakin cepat pertambahan berat badan maka akan semakin besar ransum yang akan dikonsumsi oleh ayam tersebut.

\section{Konversi Ransum}

Rataan konversi ransum kumulatif ayam Ketarras pada umur 2 sampai 12 minggu berdasarkan pola warna bulu dapat dilihat pada Tabel 7:

Secara umum konversi ransum semakin meningkat dengan bertambahnya umur. Hasil analisis ragam menunjukkan bahwa perbedaan pola warna bulu berpengaruh tidak nyata $(\mathrm{P}>0,05)$ terhadap konversi ransum kumulatif. Konversi ransum ayam Ketarras umur 2 - 12 minggu pada perlakuan P1 $(4,60)$, P2 $(4,24)$ dan P3 $(4,40)$ berbeda tidak nyata. Hal ini menunjukkan bahwa sifat kualitatif (warna bulu) tidak mempengaruhi konversi ransum. Rataan konversi ransum pada penelitian ini adalah $4,24-4,60 \mathrm{~g}$. 
Tabel 7. Rataan konversi ransum kumulatif ayam Ketarras pada umur 2 sampai 12 minggu berdasarkan pola warna bulu

\begin{tabular}{ccccc}
\hline \multirow{2}{*}{$\begin{array}{c}\text { Umur } \\
\text { (minggu) }\end{array}$} & \multicolumn{3}{c}{ Perlakuan } & \multirow{2}{*}{ Ket } \\
\cline { 2 - 4 } $2-3$ & $\mathrm{P} 1$ & $\mathrm{P} 2$ & $\mathrm{P} 3$ & $\mathrm{~ns}$ \\
$2-4$ & 2,55 & 2,69 & 2,25 & $\mathrm{~ns}$ \\
$2-5$ & 3,37 & 3,17 & 3,14 & $\mathrm{~ns}$ \\
$2-6$ & 3,08 & 3,34 & 3,18 & $\mathrm{~ns}$ \\
$2-7$ & 3,29 & 3,36 & 3,22 & $\mathrm{~ns}$ \\
$2-8$ & 3,41 & 3,37 & 3,37 & $\mathrm{~ns}$ \\
$2-9$ & 3,69 & 3,37 & 3,77 & $\mathrm{~ns}$ \\
$2-10$ & 4,04 & 3,98 & 3,97 & $\mathrm{~ns}$ \\
$2-11$ & 4,20 & 3,97 & 4,12 & $\mathrm{~ns}$ \\
$2-12$ & 4,41 & 4,09 & 4,21 & $\mathrm{~ns}$ \\
\hline
\end{tabular}

Keterangan:

P1 = Pola warna bulu gelap (coklat hitam)

P2 = Pola warna bulu putih blurik

P3 = Pola warna bulu putih

ns $=$ berbeda tidak nyata $(\mathrm{P}>0,05)$

Gunawan (2017) melaporkan bahwa konversi ransum ayam ketarras umur 2-12 minggu adalah 5,38 g. Bila dibandingkan dengan hasil penelitian Gunawan (2017), konversi ransum ayam ketarras pada penelitian ini lebih rendah. Terdapatnya perbedaan konversi ransum ayam ketarras pada penelitian ini dengan penelitian Gunawan (2017) diduga disebabkan oleh perbedaan waktu penelitian, sehingga lingkungannya berbeda. Menurut Rasyaf (2011), faktor yang mempengaruhi konversi ransum adalah kecepatan pertumbuhan, kandungan energi dalam ransum, terpenuhinya zat nutrisi dalam ransum, suhu lingkungan, kesehatan.

\section{KESIMPULAN}

Berdasarkan hasil penelitian dapat disimpulkan bahwa perbedaan pola warna bulu ayam Ketarras tidak menyebabkan performans berbeda pada umur 2 sampai 12 minggu. Perlu dilakukan penelitian lebih lanjut untuk mengetahui produksi telurnya.

\section{DAFTAR PUSTAKA}

Astuti, N. 2012. Kinerja ayam kampung dengan ransum berbasis konsentrat broiler. Prodi Peternakan Fakultas Agroindustri Universitas Mercu Buana Yogyakarta. Yogyakarta.

Darmana, W. dan M. Sitanggang 2002. Meningkatkan Produktivitas ayam Arab Petelur. Agromedia Pustaka. Jakarta.

Diana. 2012. Performans ayam Arab (Galus turcicus) periode starter yang diberi ransum dengan level protein dan energi yang berbeda. Skripsi. Program Studi Peternakan Fakultas Pertanian dan Peternakan Universitas Islam Negri Sultan Syarif Khasim Riau Pekanbaru

Galih, 2017. Produktifitas telur ayam Arras dan ayam Arab umur 40 sampai 68 minggu. Skripsi. Jurusan Peternakan Fakultas Pertanian Universitas Bengkulu.

Gunawan, E. 2017. Performans Keturunan ayam Arras dengan ayam Arab (ayam Kettaras) umur 2-12 Minggu. Skripsi. Fakultas Pertanian. Universitas Bengkulu. Bengkulu. 
Johari, S., Sutopo dan A. Santi. 2009. Frekuensi fenotipik sifat-sifat kualitatif ayam kedu dewasa. Makalah seminar kebangkitan peternakan Fakultas Peternakan Universitas Diponegoro. Semarang

Lukman, H. 2005. Evaluasi pemberian feed aditive alami berupa campuran herbal, probiotik, dan prebiotik terhadap performans, karkas dan lemak abdominal, serta HDL, LDL daging. Skripsi.Departemen Ilmu Nutrisi dan Teknologi Pakan.Institut Pertanian Bogor. Bogor.

Marliya, O. 2017. Uji Kualitas dan Aksebtibilitas Telur Ayam Ketarras sebagai Telur Ayam Kampung, Jurusan Peternakan Fakultas Pertanian Universitas Bengkulu

Nataamijaya, A. G., A. R. Setioko, B. Brahmantiyo \& K. Diwyanto. 2003. Performans dan karakteristik tiga galur ayam lokal (Pelung, Arab, dan Sentul). Prosiding Seminar Nasional Teknologi Peternakan dan Veteriner 2003.Pusat Penelitian dan Pengembangan Peternakan, Bogor.

Natalia, H., D Nista, Sunarto dan D. S. Yuni. 2005. Pengembangan Ayam
Arab. Balai Pembibitan Ternak Unggul Sembawa. Palembang

Rasyaf, M. 2011. Panduan Beternak Ayam Pedaging. Cetakan ke 4. Penebar Swadaya. Jakarta.

Rasyaf, M. 2012. Panduan Beternak Ayam Petelur. Cetakan ke 5. Penebar Swadaya Jakarta

Santoso, U. 2014. Katuk, Tumbuhan Multi Khasiat. Cetakan ke 1. Bengkulu: Badan Penerbitan Fakultas Pertanian UNIB.

Sukarini, N. E., dan A. Rifai. 2011. Pengaruh penambahan berbagai tepung hijauan terhadap performans produksi ayam Arab. Akademi Peternakan Karanganyar. Semarang.

Warwick, E. J. dan J. E. Legates. 1986. Breeding and Improvemen of Farm Animal. Mc Graw Hill Publishing: New Delhi.

Yitnosumarto, S. 1993. Perancangan Percobaan, Analisis dan Interprestasinya. Gramedia Pustaka Utama 